\title{
The preferred conformation of erythro- and threo-1,2-difluorocyclododecanes
}

\author{
Yi Wang ${ }^{1}$, Peer Kirsch ${ }^{2}$, Tomas Lebl ${ }^{1}$, Alexandra M. Z. Slawin ${ }^{1}$ \\ and David O'Hagan ${ }^{* 1}$
}

\author{
Full Research Paper \\ Address: \\ ${ }^{1}$ EastChem School of Chemistry, University of St Andrews, St \\ Andrews, KY16 9ST, UK and ${ }^{2}$ Merck KGaA, Frankfurter Str. 250, \\ 64293 Darmstadt, Germany \\ Email: \\ David O'Hagan* - do1@st-andrews.ac.uk \\ * Corresponding author \\ Keywords: \\ alicyclic chemistry; conformational analysis; cyclododecane; \\ ${ }^{19} \mathrm{~F}$ NMR; organo-fluorine chemistry; transannular interactions
}

\author{
Beilstein J. Org. Chem. 2012, 8, 1271-1278. \\ doi:10.3762/bjoc. 8.143 \\ Received: 15 March 2012 \\ Accepted: 12 July 2012 \\ Published: 10 August 2012 \\ Associate Editor: P. R. Schreiner \\ (c) 2012 Wang et al; licensee Beilstein-Institut. \\ License and terms: see end of document.
}

\begin{abstract}
Cyclododecane adopts a square-like structure with corner and edge $\mathrm{CH}_{2}$ groups. In this study erythro- and threo-1,2-difluorocyclododecanes were prepared to explore whether the two vicinal C-F bonds, with different relative configurations, preferably locate at corner/edge or edge/edge locations. Conformational analysis comparing the diastereoisomers was explored by using a combination of ${ }^{19} \mathrm{~F}\left\{{ }^{1} \mathrm{H}\right\}$ NMR spectroscopy, computational studies and, in the case of the threo isomer, X-ray structural analysis. In the lowest energy conformers for both diastereoisomers the vicinal $\mathrm{C}-\mathrm{F}$ bonds are located corner/edge, rather than edge/edge. These structures avoid placing a $\mathrm{C}-\mathrm{F}$ bond endo into the ring, and appear to benefit from $\mathrm{C}-\mathrm{CHF}-\mathrm{C}$ angle widening, which relaxes $1,4-\mathrm{H}, \mathrm{H}$ transannular interactions.
\end{abstract}

\section{Introduction}

The conformation of cyclododecane (1) in the solid state was first reported by Dunitz and Shearer in 1960 [1,2]. They showed that cyclododecane has a square topology, which can be classified as a [3333] type structure [3,4]. Their conclusion was derived from X-ray diffraction data, which could not fully resolve the structure due to a high level of disorder, but the diffraction data was used as the basis of a further computational analysis, and the structure in Figure 1 emerged as their consensus structure $[5,6]$. The structure is tensioned by transannular interactions in which there are four endo hydrogens, one on each edge pointing into the ring on the top face, and four more endo hydrogens pointing into the ring on the lower face. Each set of hydrogens forms a square, and they are spaced at van der Waals contact distances ( 2.1-2.2 $\AA$ ) to their contacted neighbours, situated at 1,4-positions on adjacent edges of the ring. This structure has two distinct types of methylene group, those located at corners of the ring and those at edges.

Recently we prepared and explored the conformation of cyclododecane ring systems carrying either one or two difluoro- 


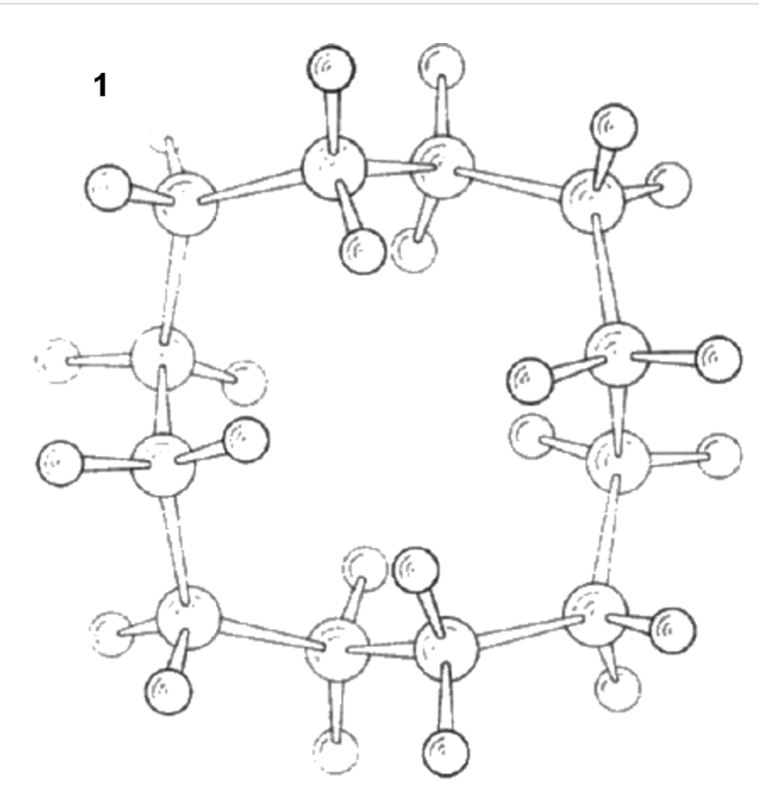

Figure 1: The Dunitz and Shearer structure of cyclododecane (1) [1,2] There are four endo hydrogens above and four below the plane of the ring, which are tensioned as they are within van der Waals contact distances. Thus the ring adopts a [3333] square-type structure. (Reproduced with permission from [1]; Copyright @ 1960 Verlag $\mathrm{GmbH}$ \& Co KGaA, Weinheim).

methylene $\left(\mathrm{CF}_{2}\right)$ groups in place of methylenes $\left(\mathrm{CH}_{2}\right)$ [7]. The study revealed that the $\mathrm{CF}_{2}$ groups always occupied corner positions. This was deduced by a combination of ${ }^{19} \mathrm{~F}$ NMR, $\mathrm{X}$-ray structure analysis and theory studies. Two reasons emerged for this. Firstly, if a C-F bond did project into the ring (endo), then the increased size of the fluorine atom relative to hydrogen increases the transannular 1,4-H,F relative to $1,4-\mathrm{H}, \mathrm{H}$ strain, by placing a fluorine in the square of hydrogen atoms on the top (or bottom) face of the ring. Secondly, the electronega- tivity of the fluorines within the $\mathrm{CF}_{2}$ group has the effect of distorting the $\mathrm{sp}^{3}$ geometry and widening the tetrahedral $\mathrm{C}-\mathrm{CF}_{2}-\mathrm{C}$ angle from around $113^{\circ}$ to about $116-118^{\circ}$ [7-9]. This angle widening has the effect of lengthening/relaxing the 1,4-H,H transannular contacts between the transverse endo hydrogens, thus leading to a lower-energy ring structure. As a consequence of these two effects, the preference for a corner over an edge location is very strong, and thus when the $\mathrm{CF}_{2}$ groups are spaced 1,4 to each other or 1,7 to each other within the ring, they occupy adjacent and opposite corners of the ring, respectively, and form stable ring systems. This is illustrated in the $\mathrm{X}$-ray structures in Figure 2. However when the $\mathrm{CF}_{2}$ groups were placed 1,6 to each other, a deliberate mismatch with respect to corner locations, the ring structure then became a distorted [4332] ring system, which is a structure that is more achievable than placing a $\mathrm{CF}_{2}$ group at an edge position of a [3333] ring system.

In this study we separated the geminal fluorine atom of the $\mathrm{CF}_{2}$ group to generate vicinal fluorines in order to explore the conformational preference of the erythro- and threo- diastereoisomers of 1,2-difluorocyclododecanes $\mathbf{5 a}$ and $\mathbf{5 b}$ (Figure 3).<smiles>FC1CCCCCCCCCC1F</smiles>

erythro $\mathbf{5 a}$<smiles>FC1CCCCCCCCCC[C@@H]1F</smiles>

threo $5 b$
Figure 3: Erythro- and threo-1,2-difluorocyclododecanes (5a and $\mathbf{5 b})$. a

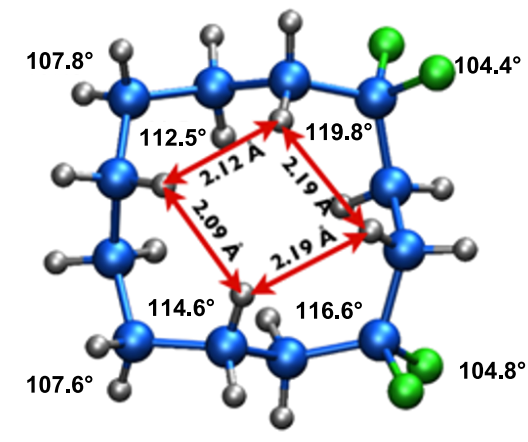

2 b

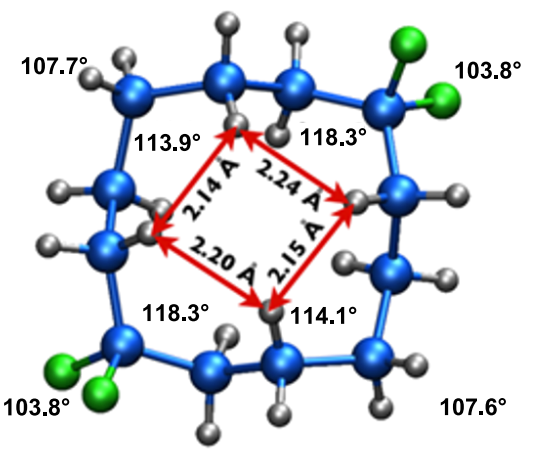

3

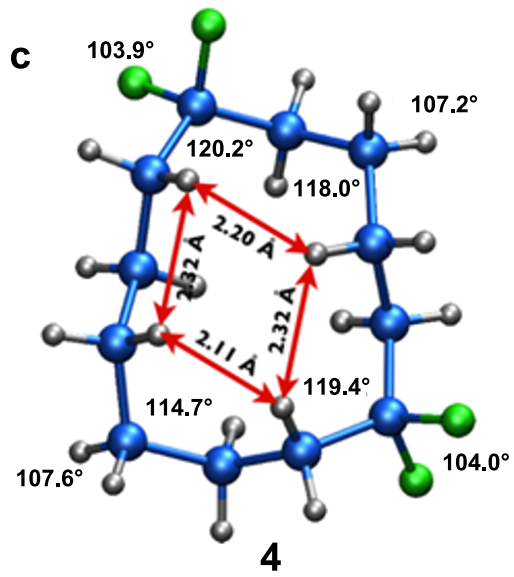

Figure 2: Crystal structures of (a) 1,1,4,4- (b) 1,1,7,7- and (c) 1,1,6,6-tetrafluorocyclododecanes (2-4), illustrating the corner preference of the $\mathrm{CF}_{2}$ groups. Structures 2 and 3 adopt a [3333] conformation, whereas 4 adopts a distorted [4332] conformation. Fluorine atoms are presented in green [7]. 
In the case of erythro- and threo-1,2-difluorocyclododecanes (5a and $\mathbf{5 b}$, respectively) it may be expected that the threo isomer $\mathbf{5 b}$ will adopt a conformation whereby the vicinal fluorines occupy a central edge/edge location, such that both $\mathrm{C}-\mathrm{F}$ bonds project exo to the ring, and do not increase the torsional strain. Also for the threo isomer $\mathbf{5 b}$, the $\mathrm{C}-\mathrm{F}$ bonds may benefit from hyperconjugative interactions with the anti-periplanar $\mathrm{C}-\mathrm{H}$ bonds, similar to that found in 1,2-difluoroethane in the well know gauche effect $[10,11]$. On the other hand, the erythro stereoisomer 5a would have a $\mathrm{C}-\mathrm{F}$ bond projecting into the ring in an endo manner, if the vicinal fluorines were edge/edge located, and thus it is anticipated that the erythro isomer $\mathbf{5 a}$ will adopt a corner/edge location for the $\mathrm{C}-\mathrm{F}$ bonds rather than an edge/edge location.

In order to test these hypotheses it was necessary to prepare different the diastereoisomers, erythro- and threo-1,2-difluorocyclododecane, and then subject them to conformational analysis by ${ }^{19} \mathrm{~F}$ NMR and X-ray structural analyses. A computational study was also carried out to explore the relative energies of the candidate edge/edge and edge/corner conformers.

\section{Results and Discussion}

\section{Synthesis}

The synthetic route to erythro- (5a) and threo-1,2-difluorocyclododecanes (5b) is shown in Scheme 1. A (1:9) mixture of cis- and trans-epoxides was treated with triethylamine trihydrofluoride [12]. This afforded diastereoisomeric fluorohydrins 7a and $\mathbf{7 b}$, which could be readily separated by chromatography. Each fluorohydrin was then treated with triflic anhydride
$[13,14]$, to generate the corresponding triflates $\mathbf{8 a}$ and $\mathbf{8 b}$. Treatment of $\mathbf{8 a}$ and $\mathbf{8 b}$ with tetrabutylammonium fluoride (TBAF) in THF was stereospecific and independently generated the erythro- or threo-1,2-difluorocyclododecanes $\mathbf{5 a}$ and $\mathbf{5 b}$. These compounds were white solids. In the case of the threo isomer only, a suitable crystal was grown such that an X-ray structure could be solved. The resultant structure, which confirmed the threo stereochemistry, is shown in Figure 4. Notably one of the $\mathrm{C}-\mathrm{F}$ bonds occupies a corner location, inconsistent with our

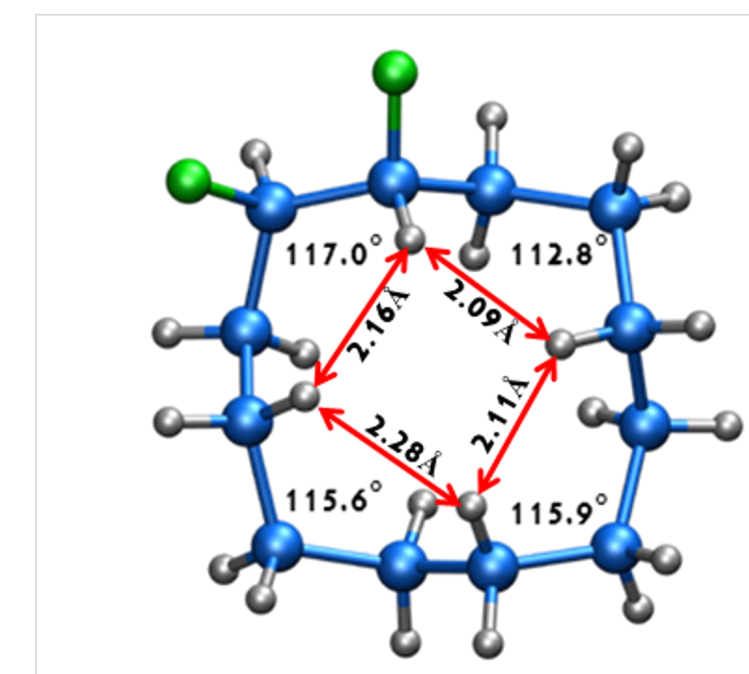

$5 b$

Figure 4: X-ray crystal structure of threo-1,2-difluorocyclododecane (5b) showing corner angles and representative transannular contact distances.

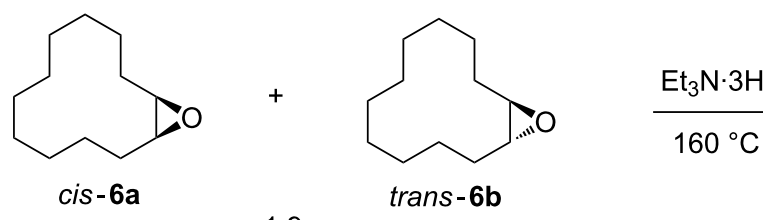

$1: 9$

trans-6b

$\underset{3}{\stackrel{\circ}{ } \mathrm{C}}$

commercially available

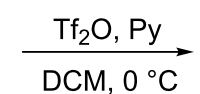<smiles>[OH2+][C@H]1CCCCCCCCCC[C@@H]1F</smiles>

$8 \mathrm{a}$

quant.

7b $\frac{\mathrm{Tf}_{2} \mathrm{O}, \mathrm{Py}}{\mathrm{DCM}, 0^{\circ} \mathrm{C}}$<smiles></smiles>

$8 b$

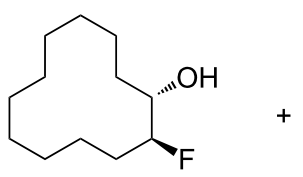

$7 \mathrm{a}$

$9 \%$<smiles>O[C@H]1CCCCCCCCCC[C@@H]1F</smiles>

$7 b$ 
preconceived expectation of a edge/edge conformation. This corner/edge conformation appears to be favoured in the solid state over the edge/edge conformation. Also the $\mathrm{C}-\mathrm{CHF}-\mathrm{C}$ angle of $117.0^{\circ}$ indicates a small rehybridisation tendency towards a wider angle, observed more dramatically with the $\mathrm{CF}_{2}$ group [7-9], and with concomitant release of angle strain.

\section{Variable-temperature (VT) ${ }^{19} \mathrm{~F}$ NMR}

Low-temperature $\left(\mathrm{CD}_{2} \mathrm{Cl}_{2}, 180 \mathrm{~K}\right){ }^{19} \mathrm{~F}\left\{{ }^{1} \mathrm{H}\right\}$ NMR experiments were carried out on both the erythro and threo isomers. The spectra are shown in Figure 5. In each case at room temperature there is a single fluorine resonance; however, on lowering of the temperature the fluorine signal resolves into an $\mathrm{AB}$-system, indicating nonequivalent fluorine environments and, thus, corner/edge locations of the $\mathrm{C}-\mathrm{F}$ bonds in each case. Vicinal edge/edge conformations would result in the magnetic equivalence of the fluorine atoms, but this is not observed. Both isomers $\mathbf{5 a}$ and $\mathbf{5 b}$ display a single resonance at room temperature $\left(25^{\circ} \mathrm{C}\right)$, indicating rapid ring interconversion on the NMR timescale. Rate constants for the ring interconversions were determined by complete lineshape analysis of the ${ }^{19} \mathrm{~F}$ NMR spectra recorded across the temperature range 180-295 K.

Fitting the experimental data to the Eyring equation [15] allowed determination of the activation parameters (see Table 1 and Supporting Information File 1).

Table 1: The activation parameters of erythro- (5a) and threo- (5b) 1,2-difluorocyclododecanes.

\begin{tabular}{|c|c|c|c|}
\hline isomer & $\begin{array}{l}\Delta G^{\#} \\
\mathrm{kcal} \cdot \mathrm{mol}^{-1}\end{array}$ & $\begin{array}{l}\Delta H^{\#} \\
\mathrm{kcal} \cdot \mathrm{mol}^{-1}\end{array}$ & $\begin{array}{l}\Delta S^{\#} \\
\mathrm{kcal} \cdot \mathrm{mol}^{-1} \mathrm{~K}^{-1}\end{array}$ \\
\hline erythro 5a & $10.5 \pm 1.5$ & $13.5 \pm 0.6$ & $10.0 \pm 2.7$ \\
\hline threo $\mathbf{5 b}$ & $9.47 \pm 1.1$ & $6.57 \pm 0.3$ & $-9.73 \pm 2.9$ \\
\hline
\end{tabular}

The overall free energy change $\left(\Delta G^{\#}\right)$ is similar in each case and both the erythro $\mathbf{5 a}$ and threo $\mathbf{5 b}$ stereoisomers have conformational energy barriers $\sim 2-3 \mathrm{kcal} \cdot \mathrm{mol}^{-1}$ higher than<smiles>F[C@H]1CCCCCCCCCC[C@@H]1F</smiles>

$25^{\circ} \mathrm{C}$ F

\section{erythro $\mathbf{5 a}$}
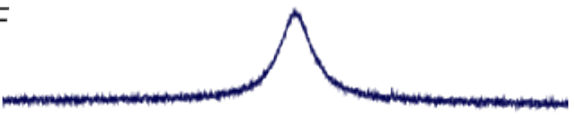

$0{ }^{\circ} \mathrm{C}$

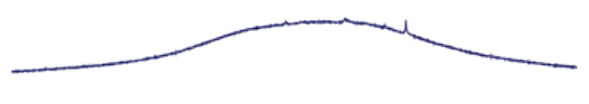

$-10^{\circ} \mathrm{C}$

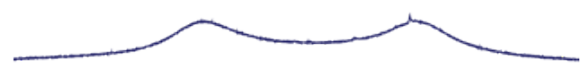

$-26{ }^{\circ} \mathrm{C}$

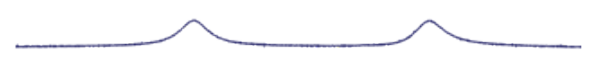

$-36^{\circ} \mathrm{C}$

$-53^{\circ} \mathrm{C}$

$-75^{\circ} \mathrm{C}$
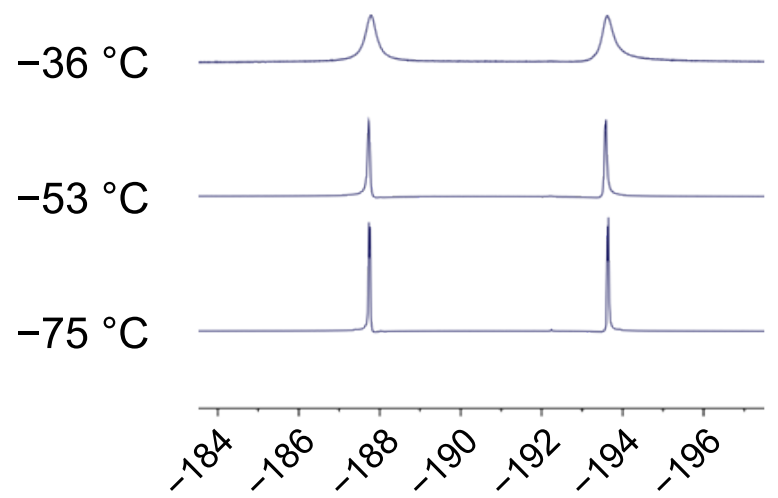<smiles>F[C@H]1CCCCCCCCCC[C@@H]1F</smiles>

threo

$5 b$

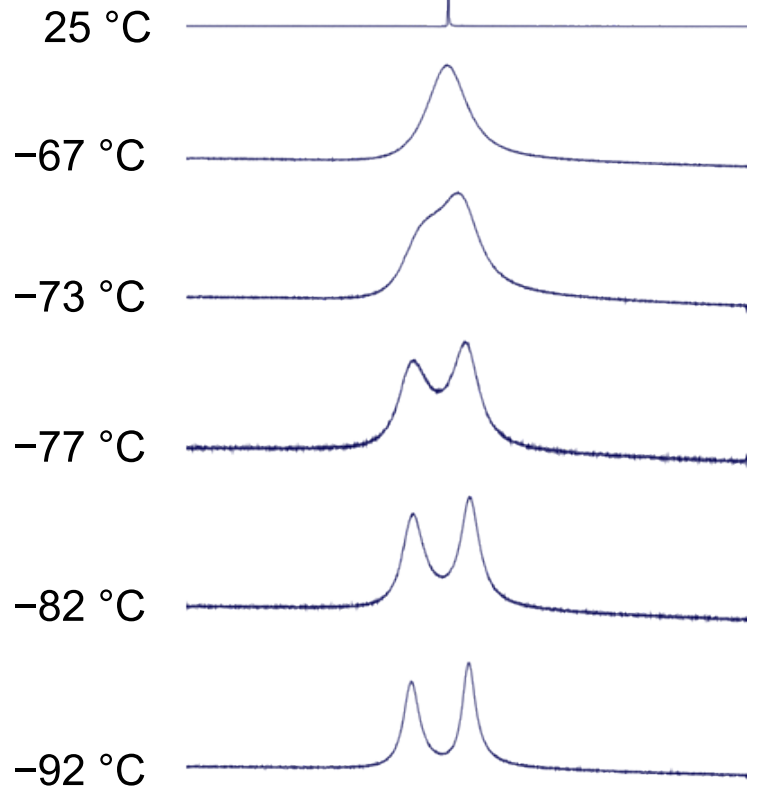

$\lambda^{90}, 9^{2}, 9^{4}, 9^{60}, 9^{80}, 2^{0}$

Figure 5: Variable-temperature ${ }^{19} \mathrm{~F}\left\{{ }^{1} \mathrm{H}\right\}$ NMR of erythro- (5a) and threo-1,2-difluorocyclododecane (5b). 
cyclododecane itself $\left(7.3 \mathrm{kcal} \cdot \mathrm{mol}^{-1}\right)$ indicating that fluorine introduces some conformational stability. The enthalpy difference $\left(\Delta H^{\#}\right)$ is significant between the isomers. The theory calculations described below suggest that the erythro isomer 5a is more stable than the threo isomer $\mathbf{5 b}$ in the ground state, thus this is most probably the major contributor to the enthalpy difference. The opposite sign in entropy $\left(\Delta S^{\#}\right)$ for each isomer makes a relatively small contribution to the overall free energy; however, the positive value for the erythro isomer is perhaps unexpected for progression towards a transition state. This may arise as a result of desolvation for this isomer.

\section{Computational study}

In order to explore conformer energies further, a theoretical study MP2/6-311+G(2d,p)//B3LYP/6-311+G(2d,p)+ZPE) [16] was carried out to assess relative ground-state energies of candidate conformers. The structures and relative energies for the erythro $\mathbf{5 a}$ and threo $\mathbf{5 b}$ isomers are shown in Figure 6. These data indicate that the corner/edge conformers are more stable than the alternative edge/edge conformers for each stereoisomer. This is consistent with the conclusions from the experimental VT ${ }^{19}$ F NMR study.
For the erythro stereoisomer 5a, three conformers I-III were considered. Conformers I and II each have a fluorine pointing into the ring (endo), and thus there is an increase in transannular ring strain, raising the energy of these conformers by 2.81 and $3.72 \mathrm{kcal} \cdot \mathrm{mol}^{-1}$ respectively above conformer III, the lowest in energy. For the threo stereoisomer $\mathbf{5 b}$, four conformers, IV-VII were considered. Conformers IV and V, which have two and one endo fluorine, respectively, are highest in energy. In particular, conformer IV with two endo fluorines has a ground-state energy of $6.65 \mathrm{kcal} \cdot \mathrm{mol}^{-1}$, the highest of all of those examined, illustrating the additive and negative impact of placing fluorines into endo orientations. Conformers VI and VII are lower in energy. It was anticipated at the outset that conformer VI may be the most favoured for the threo isomer; however, this does not appear to be the case, although the energy difference between the lowest-energy corner/edge conformer VII and edge/edge conformer VI is relatively small at $\mathrm{VI}-\mathrm{VII}=0.7 \mathrm{kcal} \cdot \mathrm{mol}^{-1}$. This theoretical observation is supported by the VT ${ }^{19} \mathrm{~F}\left\{{ }^{1} \mathrm{H}\right\}$ NMR study, which indicates nonequivalent fluorines consistent with a corner location. Also the structure of conformer VII is almost identical to that obtained experimentally by X-ray structure analysis (Figure 4).

\section{erythro 5a}
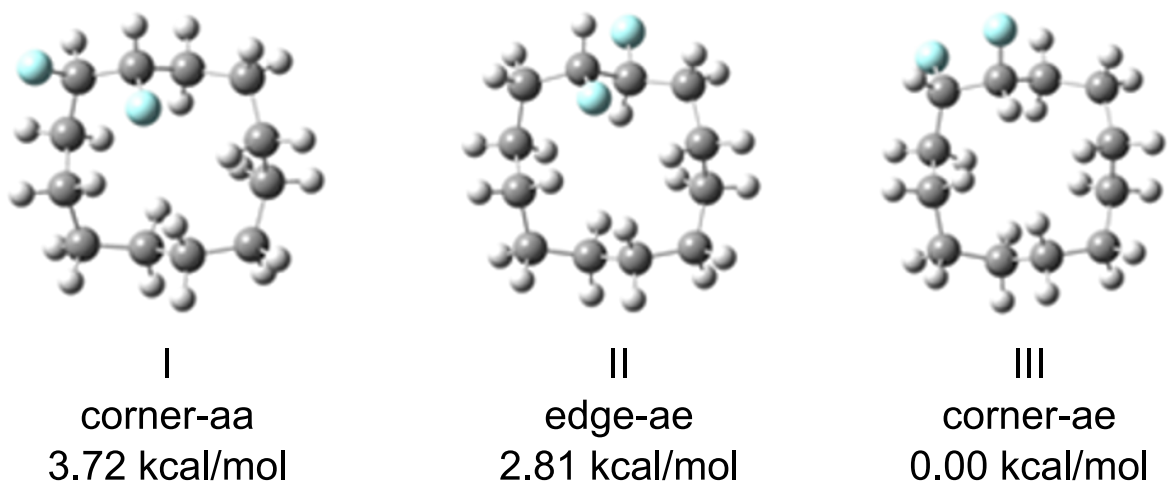

threo $5 b$

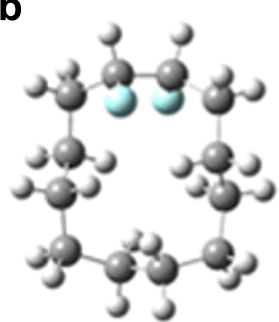

IV

edge-aa

$6.65 \mathrm{kcal} / \mathrm{mol}$

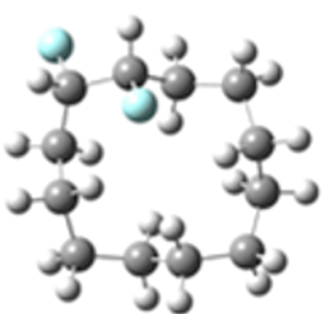

$\mathrm{V}$

corner-ae

$2.98 \mathrm{kcal} / \mathrm{mol}$

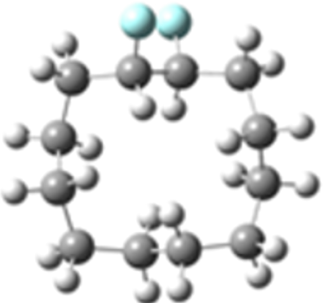

$\mathrm{VI}$ edge-ee $1.54 \mathrm{kcal} / \mathrm{mol}$

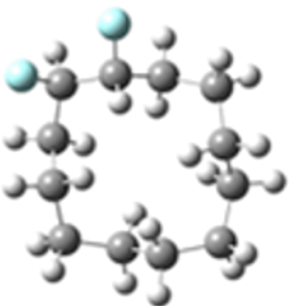

VII corner-ee $0.84 \mathrm{kcal} / \mathrm{mol}$

Figure 6: Calculated relative energies of the conformations of the erythro (5a) and threo $(\mathbf{5 b})$ stereoisomers of 1,2-difluorocyclododecane. 
It is not immediately obvious why threo $\mathbf{5 b}$ conformer VII is favoured (lower in energy) over conformer VI, although the energy difference is small $\left(\sim 0.7 \mathrm{kcal} \cdot \mathrm{mol}^{-1}\right)$. It is noteworthy that the fluorine atoms are a little closer in intramolecular dis-

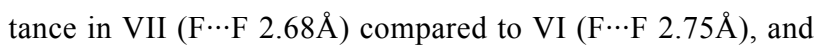
thus electrostatic repulsion does not appear to be the discriminating factor. One origin for this preference, which emerges from the theoretical study, may be the widening of the $\mathrm{C}-\mathrm{CHF}-\mathrm{C}$ angle $\left(115.62^{\circ}\right)$ in VII. The introduction of fluorine alters the hybridisation at carbon [5], and this should relieve angular strain in these tensioned ring systems relative to a strained $\mathrm{C}-\mathrm{CH}_{2}-\mathrm{C}$ angle of $\sim 115^{\circ}$ (see Table 2).

\section{Conclusion}

The erythro (5a) and threo (5b) isomers of 1,2-difluorocyclododecane were synthesised, and their preferred conformers were explored experimentally by ${ }^{19} \mathrm{~F}$ NMR, and X-ray structure analysis. A computational study was also carried out to establish favoured conformations and their relative ground-state energies. A particular focus of the study examined whether the vicinal $\mathrm{C}-\mathrm{F}$ bonds prefer to adopt corner/edge or edge/edge locations of the [3333] ring system. For each diastereoisomer it emerged that one of the $\mathrm{C}-\mathrm{F}$ bonds adopts a corner location. The second orientates exo to the ring. When the $\mathrm{C}-\mathrm{F}$ bond projects endo into the ring, the energy of the system is raised by between $2.0-3.0 \mathrm{kcal} \cdot \mathrm{mol}^{-1}$ and is disfavoured. In the case of the threo isomer $\mathbf{5 b}$, the outcome was less easy to predict, as an edge/edge structure can be achieved with both $\mathrm{C}-\mathrm{F}$ bonds exo to the ring, and with each $\mathrm{C}-\mathrm{F}$ bond benefiting from antiperiplanar $\mathrm{C}-\mathrm{H} / \mathrm{C}-\mathrm{F}$ hyperconjugative interactions. However it would appear that the corner/edge structure is still favoured for the threo isomer $\mathbf{5 b}$, as the $\mathrm{C}-\mathrm{C}-\mathrm{C}$ bond angles of $\sim 115^{\circ}$, which occur in these tensioned ring systems, are inherently less strained, due to rehybridisation/angle widening, if they carry a central fluorine atom.

\section{Experimental}

Preparation of 7a and 7b: Commercially available 1,2-epoxycyclododecane (6) (5 mmol, $0.91 \mathrm{~g}, 9: 1 \mathrm{trans} /$ cis $)$ and $\mathrm{Et}_{3} \mathrm{~N} \cdot 3 \mathrm{HF}(4.0 \mathrm{~g}, 25 \mathrm{mmol})$ was added to a Teflon-coated reactor and stirred at $160{ }^{\circ} \mathrm{C}$ for $24 \mathrm{~h}$. After cooling down, the reaction mixture was quenched with sat. $\mathrm{NaHCO}_{3}$ solution $(50 \mathrm{~mL})$ and extracted into diethyl ether $(3 \times 20 \mathrm{~mL})$. The organic layers were combined and dried $\left(\mathrm{MgSO}_{4}\right)$, and then concentrated under vacuum. Purification over silica gel, eluting with hexane and diethyl ether (90:10), yielded trans-2-fluorocyclododecanol (7a) (91 mg, 9\%) and cis-2-fluorocyclododecanol (7b) (420 mg, 41\%) as a white crystalline solid.

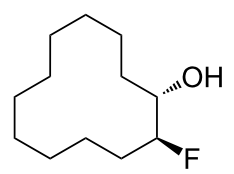

7a: $\mathrm{mp} 64-65{ }^{\circ} \mathrm{C} ;{ }^{1} \mathrm{H}$ NMR $\left(400 \mathrm{MHz}, \mathrm{CDCl}_{3}\right) \delta_{\mathrm{H}} 4.56$ (ddt, $J$ $=49.4,8.7,4.2 \mathrm{~Hz}, \mathrm{CHF}), 3.94-3.86(\mathrm{~m}, 1 \mathrm{H}, \mathrm{CHOH}), 2.27$ (t, $J$ $=3.5 \mathrm{~Hz}, 1 \mathrm{H}, \mathrm{CHOH})$ and $1.92-0.84\left(\mathrm{~m}, 20 \mathrm{H}, 10 \times \mathrm{CH}_{2}\right)$; ${ }^{13} \mathrm{C}$ NMR $\left(100 \mathrm{MHz}, \mathrm{CDCl}_{3}\right) \delta_{\mathrm{C}} 95.3(\mathrm{~d}, J=166 \mathrm{~Hz}, \mathrm{CHF})$, 71.4 (d, $J=18 \mathrm{~Hz}, \mathrm{CHOH}), 28.7$ (d, $J=5.5 \mathrm{~Hz}, \mathrm{CH}_{2}$ ), 27.8 (d, $\left.J=21 \mathrm{~Hz}, \mathrm{CH}_{2}\right), 24.0\left(\mathrm{~d}, J=1.6 \mathrm{~Hz}, 2 \times \mathrm{CH}_{2}\right), 23.7(\mathrm{~d}, J=$ $\left.2.8 \mathrm{~Hz}, 2 \times \mathrm{CH}_{2}\right), 22.6\left(\mathrm{~d}, J=2.9 \mathrm{~Hz}, 2 \times \mathrm{CH}_{2}\right), 20.6\left(\mathrm{CH}_{2}\right)$, $20.4\left(\mathrm{~d}, J=2.8 \mathrm{~Hz}, \mathrm{CH}_{2}\right) ;\left\{{ }^{1} \mathrm{H}\right\}{ }^{19} \mathrm{~F}$ NMR $\left(376 \mathrm{MHz}, \mathrm{CDCl}_{3}\right)$ $\delta_{\mathrm{F}}-194.0(\mathrm{CHF})$; LRMS-ESI $(\mathrm{m} / \mathrm{z}):[\mathrm{M}+\mathrm{Na}]^{+}$calcd for $\mathrm{C}_{12} \mathrm{H}_{23} \mathrm{OFNa}$, 225.16; found, 225.06 .

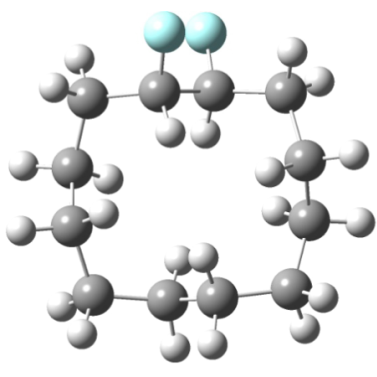

VI

edge-ee

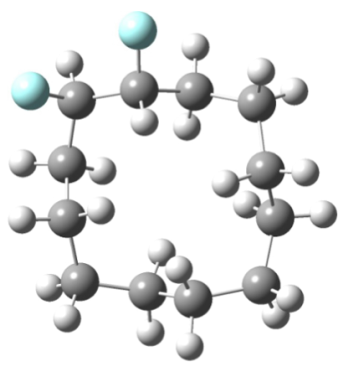

VII

corner-ee

\begin{tabular}{lllll}
\hline threo 5b & top left corner $\left[^{\circ}\right]$ & top right corner $\left[{ }^{\circ}\right]$ & bottom left corner $\left[{ }^{\circ}\right]$ & bottom right corner $\left[{ }^{\circ}\right]$ \\
\hline VI & $113.42\left(\mathrm{CH}_{2}\right)$ & $113.41\left(\mathrm{CH}_{2}\right)$ & $115.16\left(\mathrm{CH}_{2}\right)$ & $115.21\left(\mathrm{CH}_{2}\right)$ \\
VII & $115.62(\mathrm{CHF})$ & $113.91\left(\mathrm{CH}_{2}\right)$ & $115.09\left(\mathrm{CH}_{2}\right)$ & $114.32\left(\mathrm{CH}_{2}\right)$
\end{tabular}




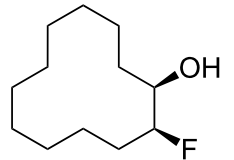

7b: mp 84-86 ${ }^{\circ} \mathrm{C} ;{ }^{1} \mathrm{H}$ NMR $\left(400 \mathrm{MHz}, \mathrm{CDCl}_{3}\right) \delta_{\mathrm{H}} 4.70(\mathrm{dtd}, J$ $=47.3,6.0,1.7 \mathrm{~Hz}, 1 \mathrm{H}, \mathrm{CHF}), 3.99-3.88(\mathrm{~m}, 1 \mathrm{H}, \mathrm{CHOH}), 1.81$ $(\mathrm{d}, J=5.4 \mathrm{~Hz}, 1 \mathrm{H}, \mathrm{CHOH})$ and $1.83-1.33\left(\mathrm{~m}, 20 \mathrm{H}, 10 \times \mathrm{CH}_{2}\right)$; ${ }^{13} \mathrm{C}$ NMR $\left(75 \mathrm{MHz}, \mathrm{CDCl}_{3}\right) \delta_{\mathrm{C}} 95.4(\mathrm{~d}, J=168 \mathrm{~Hz}, \mathrm{CHF})$, $71.6(\mathrm{~d}, J=20 \mathrm{~Hz}, \mathrm{CHOH}), 28.3\left(\mathrm{~d}, J=7 \mathrm{~Hz}, \mathrm{CH}_{2}\right), 25.2$ (d, $J$ $\left.=21 \mathrm{~Hz}, \mathrm{CH}_{2}\right), 24.6\left(\mathrm{CH}_{2}\right), 24.3\left(\mathrm{CH}_{2}\right), 23.8\left(\mathrm{CH}_{2}\right), 23.6$ $\left(\mathrm{CH}_{2}\right), 21.7\left(2 \times \mathrm{CH}_{2}\right), 21.4\left(\mathrm{~d}, J=5 \mathrm{~Hz}, \mathrm{CH}_{2}\right), 21.3\left(\mathrm{CH}_{2}\right)$; $\left\{{ }^{1} \mathrm{H}\right\}{ }^{19} \mathrm{~F}$ NMR $\left(376 \mathrm{MHz}, \mathrm{CDCl}_{3}\right) \delta_{\mathrm{F}}-191.1$ (CHF); LRMS-ESI $(\mathrm{m} / \mathrm{z}):[\mathrm{M}+\mathrm{Na}]^{+}$calcd for $\mathrm{C}_{12} \mathrm{H}_{23} \mathrm{OFNa}$, 225.16; found, 225.07.

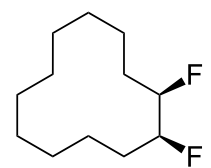

Erythro isomer 5a: To a solution of $7 \mathbf{a}(0.11 \mathrm{~g}, 0.5 \mathrm{mmol})$ in DCM $(5 \mathrm{~mL})$ at $0{ }^{\circ} \mathrm{C}$ was added pyridine $(80 \mu \mathrm{L}, 1 \mathrm{mmol}$, 2 equiv) and $\mathrm{Tf}_{2} \mathrm{O}(130 \mu \mathrm{L}, 0.7 \mathrm{mmol}, 1.4$ equiv). The resulting mixture was stirred for $1 \mathrm{~h}$ and the solvent was removed under vacuum. The residue containing the trans-fluorotriflate $\mathbf{8 a}$ was dissolved in THF ( $3 \mathrm{~mL})$, and TBAF solution $(1 \mathrm{~mL}, 1 \mathrm{M}$ in THF, $1 \mathrm{mmol}$ ) was added dropwise. The reaction mixture was stirred at $\mathrm{rt}$ for $48 \mathrm{~h}$ and monitored by ${ }^{19} \mathrm{~F}$ NMR. Purification over silica gel, eluting with $1 \%$ diethyl ether in cyclohexane yielded erythro-difluorocyclododecane 5a (21 mg, 21\%) as a white solid: mp $57{ }^{\circ} \mathrm{C} ;{ }^{1} \mathrm{H} \mathrm{NMR}\left(400 \mathrm{MHz}, \mathrm{CDCl}_{3}\right) \delta_{\mathrm{H}}$ $4.81-4.64$ (tdd, $J=48.3,24.1,6.3 \mathrm{~Hz}, 2 \mathrm{H}, 2 \times \mathrm{CHF}$ ), 1.80-1.73 $\left(\mathrm{m}, 4 \mathrm{H}, 2 \times \mathrm{CH}_{2}\right), 1.44-1.33\left(\mathrm{~m}, 16 \mathrm{H}, 8 \times \mathrm{CH}_{2}\right) ;{ }^{13} \mathrm{C} \mathrm{NMR}$ $\left(75 \mathrm{MHz}, \mathrm{CDCl}_{3}\right) \delta_{\mathrm{C}} 92.5(\mathrm{dd}, J=174,20 \mathrm{~Hz}, 2 \times \mathrm{CHF}), 26.9$ $\left(2 \times \mathrm{CH}_{2}\right), 25.6\left(\mathrm{dd}, J=21,6 \mathrm{~Hz}, \mathrm{CH}_{2}\right), 24.0\left(4 \times \mathrm{CH}_{2}\right), 21.6$ $\left(2 \times \mathrm{CH}_{2}\right), 21.0\left(\mathrm{CH}_{2}\right), 20.9\left(\mathrm{CH}_{2}\right) ;\left\{{ }^{1} \mathrm{H}\right\}{ }^{19} \mathrm{~F} \mathrm{NMR}(376 \mathrm{MHz}$, $\left.\mathrm{CDCl}_{3}\right) \delta_{\mathrm{F}}-191.0(\mathrm{CF})$; HRMS-ESI $(\mathrm{m} / \mathrm{z}):[\mathrm{M}+\mathrm{Na}]^{+}$exact mass calcd for $\mathrm{C}_{12} \mathrm{H}_{22} \mathrm{~F}_{2} \mathrm{Na}$, 227.1587; found, 227.1591.

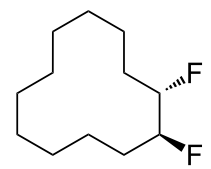

Threo isomer $\mathbf{5 b}$ : Similar to the erythro compound, $\mathbf{5 b}$ was obtained from cis-7b in $25 \%$ as a white solid: mp $61{ }^{\circ} \mathrm{C}$; ${ }^{1} \mathrm{H}$ NMR $\left(400 \mathrm{MHz}, \mathrm{CDCl}_{3}\right) \delta_{\mathrm{H}} 4.81-4.64(\mathrm{~m}, 2 \mathrm{H}, 2 \times \mathrm{CHF})$, 2.10-1.23 (m, 20H, $\left.10 \times \mathrm{CH}_{2}\right) ;{ }^{13} \mathrm{C}$ NMR $\left(100 \mathrm{MHz}, \mathrm{CD}_{2} \mathrm{Cl}_{2}\right)$ $\delta_{\mathrm{C}} 92.4(\mathrm{dd}, J=176,19 \mathrm{~Hz}, 2 \times \mathrm{CHF}), 29.7\left(\mathrm{CH}_{2}\right), 27.8(\mathrm{dd}, J$ $\left.=15,12 \mathrm{~Hz}, 2 \times \mathrm{CH}_{2}\right), 24.0\left(2 \times \mathrm{CH}_{2}\right), 23.7\left(2 \times \mathrm{CH}_{2}\right), 22.5$ $\left(2 \times \mathrm{CH}_{2}\right), 20.4\left(\mathrm{CH}_{2}\right) ;\left\{{ }^{1} \mathrm{H}\right\}^{19} \mathrm{~F}$ NMR $\left(376 \mathrm{MHz}, \mathrm{CDCl}_{3}\right) \delta_{\mathrm{F}}$ $-193.6(\mathrm{CF})$; HRMS-ESI $(\mathrm{m} / \mathrm{z}):[\mathrm{M}+\mathrm{Na}]^{+}$exact mass calcd for $\mathrm{C}_{12} \mathrm{H}_{22} \mathrm{~F}_{2} \mathrm{Na}$, 227.1587; found, 227.1595.

\section{Supporting Information}

The Supporting Information contains NMR spectra and results of the differential scanning calorimetry,

variable-temperature NMR, and computational studies.

\section{Supporting Information File 1}

Additional data.

[http://www.beilstein-journals.org/bjoc/content/ supplementary/1860-5397-8-143-S1.pdf]

\section{Acknowledgements}

We thank the European Research Council for an Advanced Investigator Grant (DO'H). We also thank the EPSRC Mass Spectrometry service at the University of Swansea for analyses.

\section{References}

1. Dunitz, J. D.; Shearer, H. M. M. Helv. Chim. Acta 1960, 43, 18-35. doi:10.1002/hlca.19600430104

2. Bürgi, H.-B.; Dunitz, J. D. Helv. Chim. Acta 1993, 76, 1115-1166. doi:10.1002/hlca.19930760303

3. Dale, J. Acta Chem. Scand. 1973, 27, 1115-1129. doi:10.3891/acta.chem.scand.27-1115

4. Eliel, E. L.; Wilen, S. H. Stereochemistry of Organic Compounds; Wiley-Interscience: New York, 1994.

5. Anet, F. A. L.; Rawdah, T. N. J. Am. Chem. Soc. 1978, 100, 7166-7171. doi:10.1021/ja00491a007

6. Atavin, E. G.; Mastryukov, V. S.; Allinger, N. L.; Almenningen, A.; Seip, R. J. Mol. Struct. 1989, 212, 87-95. doi:10.1016/0022-2860(89)85069-0

7. Skibinski, M.; Wang, Y.; Slawin, A. M. Z.; Lebl, T.; Kirsch, P.; O'Hagan, D. Angew. Chem., Int. Ed. 2011, 50, 10581-10584. doi:10.1002/anie.201105060

8. Dasaradhi, L.; O'Hagan, D.; Petty, M. C.; Pearson, C. J. Chem. Soc., Perkin Trans. 2 1995, 221-225. doi:10.1039/p29950000221

9. O'Hagan, D. Chem. Soc. Rev. 2008, 37, 308-319. doi:10.1039/b711844a

10. Goodman, L.; Gu, H.; Pophristic, V. J. Phys. Chem. A 2005, 109 , 1223-1229. doi:10.1021/jp046290d

11. Souza, F. R.; Freitas, M. P.; Rittner, R. J. Mol. Struct. 2008, 863, 137-140. doi:10.1016/j.theochem.2008.06.003

12. Michel, D.; Schlosser, M. Tetrahedron 2000, 56, 4253-4260. doi:10.1016/S0040-4020(00)00351-3

13. Nicoletti, M.; O'Hagan, D.; Slawin, A. M. Z. J. Am. Chem. Soc. 2005, 127, 482-483. doi:10.1021/ja045299q

14. Durie, A. J.; Slawin, A. M. Z.; Lebl, T.; Kirsch, P.; O'Hagan, D. Chem. Commun. 2011, 47, 8265-8267. doi:10.1039/c1cc13016a 15. Eyring, H. J. Chem. Phys. 1935, 3, 107-115. doi:10.1063/1.1749604 
16. Gaussian 03, Revision D.01: M. J. Frisch et al. [see Supporting Information], Gaussian, Inc., Wallingford CT, 2004. The minimum geometries were optimised at the B3LYP/6-311+G(2d,p) level of theory, and were verified to have only positive eigenfrequencies. The energies of the conformers were calculated at the MP2/6-311+G(2d,p) level of theory, by using both B3LYP/6-311+G(2d,p) and $M 06-2 X / 6-311+G(2 d, p)$ geometries and zero-point energies. There are slight energy differences but no qualitative changes in the relative energies.

\section{License and Terms}

This is an Open Access article under the terms of the Creative Commons Attribution License

(http://creativecommons.org/licenses/by/2.0), which permits unrestricted use, distribution, and reproduction in any medium, provided the original work is properly cited.

The license is subject to the Beilstein Journal of Organic Chemistry terms and conditions:

(http://www.beilstein-journals.org/bjoc)

The definitive version of this article is the electronic one which can be found at: doi: $10.3762 /$ bjoc. 8.143 